NBER WORKING PAPER SERIES

\title{
FROM CHRONIC INFLATION TO CHRONIC DEFLATION: FOCUSING ON EXPECTATIONS AND LIQUIDITY DISARRAY SINCE WWII
}

\author{
Guillermo A. Calvo \\ Working Paper 22535 \\ http://www.nber.org/papers/w22535 \\ NATIONAL BUREAU OF ECONOMIC RESEARCH \\ 1050 Massachusetts Avenue \\ Cambridge, MA 02138 \\ August 2016
}

This is an abridged version of a paper, under the same title, prepared for the World Bank conference entitled The State of Economics, The State of the World, held in Washington, DC, June 8 and 9, 2016. I am thankful to Edmar Bacha, Sara Calvo, Fabrizio Coricelli, Roque Fernandez, Arvid Lukauscas, and Pablo Ottonello for valuable comments. The views expressed herein are those of the author and do not necessarily reflect the views of the National Bureau of Economic Research.

The author has disclosed a financial relationship of potential relevance for this research. Further information is available online at http://www.nber.org/papers/w22535.ack

NBER working papers are circulated for discussion and comment purposes. They have not been peer-reviewed or been subject to the review by the NBER Board of Directors that accompanies official NBER publications.

(C) 2016 by Guillermo A. Calvo. All rights reserved. Short sections of text, not to exceed two paragraphs, may be quoted without explicit permission provided that full credit, including () notice, is given to the source. 
From Chronic Inflation to Chronic Deflation: Focusing on Expectations and Liquidity Disarray Since WWII

Guillermo A. Calvo

NBER Working Paper No. 22535

August 2016

JEL No. E31,E41,E42,E44

\begin{abstract}
$\underline{\text { ABSTRACT }}$
The paper discusses policy relevant models, going from (1) chronic inflation in the 20th century after WWII, to (2) credit sudden stop episodes that got exacerbated in Developed Market economies after the 2008 Lehman crisis, and appear to be associated with chronic deflation. The discussion highlights the importance of expectations and liquidity, and warns about the risks of relegating liquidity to a secondary role, as has been the practice in mainstream macro models prior to the Great Recession.
\end{abstract}

Guillermo A. Calvo

Columbia University

School of International and Public Affairs

420 West 118th St, Room 1303B

MC3332

New York, NY 10027

and NBER

gc2286@columbia.edu 


\section{Introduction}

The organizers of this conference have asked me to distill in a few pages my experience with macroeconomics, focusing on issues that are relevant for policymaking. After several false starts, I concluded that I could better serve the objective if I identified a few theoretical topics that helped in the discussion of critical policy issues during the period covered. Rational Expectations (RE) stands up, given its role in the flourishing of macroeconomics since the 1970s. Whether or not one endorses its relevance for positive theory, RE has proven to be immensely useful to sort out analytical issues and offer useful insights on applications. Like the Modigliani-Miller theorem or Ricardian equivalence, the RE insights provide benchmarks that shed light even on cases in which RE do not hold.

Macroeconomics is a very rich and varied field. To keep the paper within reasonable bounds I confined the discussion to two grand themes, namely, Chronic Inflation and Chronic Deflation, and associated issues. Chronic inflation took center stage in Developed Market economies (DMs) in the 1970s (a period called the Great Inflation), and in Emerging Market economies (EMs) during much of the $20^{\text {th }}$ century after WWII. The Great Inflation has been subject to a good number of studies (for a recent discussion, see Bordo and Orphanides (2013) and McKinnon (2013)). Therefore I will focus on EM episodes. Simple rules for stopping inflation, inspired by available theory, failed to work and, in several instances, gave rise to serious distortions and costly crises. On the other hand, chronic deflation is galvanizing world attention since the dramatic financial crisis episodes in EMs and, more recently, the ongoing Great Recession that started in 2007.

Research on EM chronic Inflation focused mostly on local or domestic factors and, as a general rule, assumed that DMs were stable and provided the services of deep capital markets. This view started to be challenged by the rise of EM financial crises in which external factors have a significant, if not necessarily dominant, role, e.g., the Debt crisis in the 1980s - partly triggered by Volcker's stabilization program - and Mexico 'Tequila' crisis in 1994/5, which followed on the heels of a more modest but still important rise in US interest rates. These crises involved a host of financial factors, but the conventional wisdom tended to attribute them to EM weak domestic institutions and domestic policy mistakes. Global capital markets might have played a role, but they were not seen as the main culprit. This view proved harder to defend after the Asia/Russia crises in 1997/8, because some of epicenter economies had followed the Washington Consensus. At any rate, the succession of these crises gave a strong impetus to research that pointed sharply in a different direction. For example, towards Sudden Stop, i.e., severe supply-driven crunch in international capital flows, a phenomenon alien to well-oiled financial markets, for example. Moreover, given that the above crises involved several economies outside the crisis epicenter, research focused on systemic Sudden Stop. This set off a search for factors that may turn a regular contraction in international capital flows into systemic Sudden Stop (e.g., Calvo (1998), Calvo, Izquierdo and Mejía (2016), Cavallo and Frenkel (2008)). 
These crises raised the suspicion that the explanation went beyond standard "fundamentals" and that liquidity phenomena were at work. "Liquidity" is a slippery word. For my purposes here, it will suffice to define Liquidity services as the services provided by assets or, more generally, arrangements that may facilitate market transactions. Assets that provide those services will be called liquid assets. This does not imply that they are mostly employed as means of exchange. Liquid assets could be easily transformed into means of exchange but could be held as store of value or employed as credit collateral, for example. It is important to notice, though, that liquidity services depend on implicit compacts in which the equilibrium value of, say, a liquid asset is a function of the compacts themselves. Therefore, Liquidity is inherently illusory. Its value can collapse on the spur of the moment, giving rise to what is usually called Liquidity Crunch. Moreover, the latter can occur in absence of real shocks. To be true, real and liquidity shocks are seldom independent of each other. The main point, though, is that liquidity shocks can be rationalized without appealing to other kinds of shocks, e.g., TFP shocks. In fact, as argued below, liquidity shocks can give rise to Sudden Stops, and issues associated with Liquidity Trap and Price Deflation.

In a nutshell, the paper will be divided in two parts, the motivation of which will become self-evident as we proceed. Expectations, spiced up with chronic inflation issues, will be the theme of the first part of the paper; while Liquidity, spiced up with recent capital market episodes, will be the theme of the second part. Context and more details follow.

\section{Setting the Stage and Overview}

Most people would likely agree that Keynes's (1936) General Theory (GT) played a pivotal role in establishing macroeconomics as a field different from, but not incompatible with, microeconomics. The GT was born during the Great Depression and was greatly influenced by issues that have become once again relevant during the Great Recession, e.g., Liquidity Trap. The GT downplayed the relevance of monetary policy for the recovery phase, and gave rise to the view that "money does not matter." The appeal of this view, however, started to fade in the wake of WWII when inflation spiked, the world economy recovered from the initial slump and started to grow at relatively high rates, despite the large contraction of public expenditure after the war. As a result, Liquidity Trap became a bogeyman of the past, and the view that "money matters" came back with renewed vigor. Friedman and Schwartz (1963), for instance, argues that the Fed caused the Great Depression by ignoring the harmful effects of price collapse and failing to adopt a more aggressive easy-money stance. The relevance of monetary policy got further support from the 1970s Great Inflation episode in DMs (see Bordo and Orphanides (2013), McKinnon (2013)), and Chronic Inflation in EMs (see Calvo and Végh (1995)). 
First attempts to accommodate inflation in a Keynesian context involved sticking a Phillips curve (an empirical regularity that suggests a tradeoff between inflation and unemployment) in Hicks (1937) IS/LM model, subject to little microeconomic backing (or microfoundations). This gave rise to a highly fruitful literature around the question of whether the tradeoff could be used to lowering unemployment by raising the rate of inflation. This literature is very well known and needs not be discussed in great detail here (see Gordon (2011)). However, I think it is worth pointing out that the Phillips curve literature brought "expectations" to center stage and helped to establish the view that in the long run inflation is ineffective for lowering unemployment, and could even make it worse (see Phelps (1972) and (Friedman (1977)). This view got further support from the Rational Expectations (RE) literature, in which context it can be shown that inflation ineffectiveness could also hold in the short run (Lucas (1972)) and, more fundamentally, that empirical regularities like the Phillips curve could be misleading for policymaking (Lucas (1976), Sargent and Wallace (1981)).

Moreover, the RE literature illustrated the possibility that frank and wellintentioned policymakers could throw the economy into a destructive black hole, given that in a RE context policymaking is subject to a serious birth defect: Time Inconsistency. Time Inconsistency arises when policymakers renege from earlier policy announcements or commitments. It is a birth defect because policymakers have incentives to engage in time inconsistency, even though cheating is not in their DNAs, their foremost objective is to maximize social welfare and, not a minor detail, RE imply that individuals cannot be easily fooled (see Kydland and Prescott (1977), Calvo (1978)). The time inconsistency literature offers support for the adoption of rules rather than discretion; and central bank independence is a natural corollary. All of these insights are in the toolkit of modern macroeconomists, and several have already been incorporated in governments' macroeconomic models around the globe.

The RE approach allows analyzing policy credibility issues in isolation from other perhaps important but disparate issues like the public's imperfect information about the relevant model. RE does not answer all relevant questions concerning policy credibility but signifies a major step forward compared to the case in which expectations are assumed to be backward looking, e.g., adaptive expectations. I will illustrate this by discussing some key policy roadblocks faced by EMs subject to chronic inflation problems in Section III.

As pointed out in the Introduction, since the mid 1990s the world economy has been buffeted by crises in which the role of financial dysfunction became increasingly evident. Moreover, these crises are severe and bear an eerie resemblance to the Great Depression. Expressions like Liquidity Trap or Price Deflation, popular in the 1930s, have become part of the daily lingo. This prompted the profession to look back to the 1930s and to brush up on the rich menu of new financial instruments that were created since the 1990s (see Eichengreen (2015), Ohanian (2016)). Prior to that, a macroeconomist could get her paper published in a top-ranked journal by 
assuming, say, that debt contracts took the form of state-contingent bonds, free from default risks. Moreover, she would not have faced major referee's objections if the paper assumed that liquidity was confined to an object called money, which did not interfere in a major way with the workings of the capital market. Issues in which unplanned over-indebtedness and default are the order of the day could not be accommodated in that type of model - and the long time to recovery that we are currently experiencing, accompanied by unrelenting deflationary forces, particularly in the Eurozone and Japan, even less so. This is very troubling and policymakers are clamoring for a rapid analytical response.

What to do? Compared to the tame "reality" prior to the Great Recession, the new reality looks extremely complex. It is, thus, easy to fall in the temptation of increasing models' complexity. This could be a serious mistake. Taking that route might make macroeconomics look like a feather in the wind - which is driven by the flow but it is unable to change the direction of the wind. For macroeconomic policy to have a chance to make a difference, theory has to identify a few key factors that could have major impact on the direction of the wind. As mentioned in the Introduction, I think Liquidity is one of them, and I will argue that one can get useful insight tidbits ('intuition pumps,' as Krugman (2011) calls them) by setting Liquidity at the center of the macro universe. This will be fleshed out in Section IV.

Much of the literature that I refer to is available in print (especially that in Section III) and, therefore, I thought that it would be more useful if I focused on the flow of ideas and leave out technicalities, unless they are necessary to clarify the argument. I should note, incidentally, that I will confine the discussion to narrow economic models, and will have to apologize for not covering attendant and highly relevant political economy issues. 


\section{Chronic Inflation: Theory and Practice in EMs}

Chronic inflation - i.e., high inflation and/or stop-and-go high inflation episodes that occur over an extended period of time - has been the nemesis of several large EMs during the $20^{\text {th }}$ century (see, e.g., Dornbusch and Simonsen (1983), Bruno et al (1988), Bruno et al (1991)). Many stabilization programs employed the exchange rate as a nominal anchor. This was prompted by the existence of shallow domestic capital markets that made interest rates ineffective monetary policy instruments, and the growing evidence that monetary aggregates have a weak and volatile link with inflation - especially when inflation rates are high. In the 1970s, exchangerate-based stabilization programs were expected to produce quick results. This view was based on the belief that purchasing-power parity will bite and force domestic prices to grow at about the same rate as international prices, plus the rate of devaluation. In general, this was not to happen. Domestic prices continued unabated and caused unwanted (and, I must say, unexpected for many well-trained economists) major real currency appreciation. Moreover, many of these programs started with a consumption boom that increased fiscal revenue and gave the impression that fiscal imbalance - a common feature in high inflation economies was going away without additional sacrifice. These optimistic expectations were hard to change because, of course, policymakers (and international financial institutions, especially those that endorsed these stabilization and reform programs) became enthusiastic cheerleaders. Besides, as I will argue below, some of the popular monetary models until 1970s were unsuitable for discussing some critical issues like imperfect policy credibility.

III.1. Imperfect Credibility and Excessive Inflation. To motivate this section, I will start by referring to a provocative paper by Milton Friedman (1971) that, abstracting from credibility issues, concludes that inflation in several seignioragedependent economies was excessive, in the sense that a lower rate of inflation would collect higher seigniorage. This looks puzzling. However, the puzzle is a result of focusing on a restricted set of policy options. Friedman (1971) focuses on permanent or steady state inflation paths and, thus, rules out inflation spikes. If the public is taken by surprise, for example, it can easily be shown that inflation spikes could be effective in further increasing revenue from inflation.

To illustrate, consider a standard model in which the demand for money is a decreasing function of the expected rate of inflation. Suppose inflation is set to maximize seigniorage à la Friedman (1971), and consider an unexpected once-andfor-all spike in the rate of inflation, coupled with a credible policy announcement that future inflation will remain unchanged. The inflation spike lowers the stock of real money but it does not affect the demand for money, because expected inflation would stay the same. Thus, the public will be willing to spend extra resources to restore the steady-state demand for money, which results in seigniorage higher than what would be attained if authorities stuck to Friedman's seigniorage-maximizing inflation rate. 
Repeated use of surprise inflation is unlikely to be successful in increasing seigniorage, because the public will start to expect a rate of inflation larger than the one that optimizes steady-state revenue from inflation. Thus, eventually the economy may land on the excessive-inflation territory highlighted in Friedman (1971). However, this is not due to an elementary economics error on the side of the central bank, as Friedman's results might lead us to conclude. An inflation spike is, in the short run, one of the cheapest and most expeditious manners for securing additional fiscal revenue. Moreover, this "carrot" is always there. As noted, though, a problem arises if the government repeatedly reaches out for the carrot. But, even in this case, the evidence presented in Friedman (1971) does not prove that authorities were making an error. To assess that, one needs information of how quickly the public catches up with the inflation-spike strategy.

The central lesson from the above example is that there are harmful incentives that lead policymakers to implement inflation levels that they may eventually come to regret. These incentives are no rarity; they are very common in economies that do not have the instruments to reach a first-best equilibrium. Moreover, these incentives cannot be ruled out even under Rational Expectations. This is shown in the Time Inconsistency literature (see, e.g., Kydland and Prescott (1977), Calvo (1978)). However, there is room for policy. In the above example one could try to neutralize these harmful incentives if the central bank is banned from extending loans to the fiscal authority. ${ }^{1}$

Inflation surprise is effective for liquidating the real value of financial assets other than high-powered money. Important examples are public debt obligations denominated in nominal terms (e.g., principal or coupon not indexed to the price level). Thus, in designing public debt instruments policymakers should take these seigniorage incentives into account, especially if the fiscal authority is constrained to small fiscal room. Calvo and Guidotti (1990) address these issues and discuss public debt configurations in terms of maturity and indexation. Price indexation, for example, would remove incentives for surprise inflation but, on the other hand, may make public debt service too rigid in the face of real shocks (more on this in Subsection III.3). Moreover, short-maturity nominal debt may also remove incentives for surprise inflation if fiscal cost grows exponentially with the rate of inflation (e.g., making the cost of a price-change surprise much higher if it takes

${ }^{1}$ However, this is not a foolproof solution to the excessive-inflation problem. See Calvo (1986 a) for a discussion of an episode in which the central bank of Argentina was banned from lending to the treasury and, hence, private banks took that role. When the treasury went bankrupt, though, the central bank bailed out private banks, which was equivalent to taking a long and tortuous route to lending to the treasury. 
place, say, in a day than in a month). But, on the other hand, the government gives up the resilience provided by long-term debt. ${ }^{2}$

Remark 1. An Embarrassing Error and a Warning. These insights were not common knowledge at the time of Friedman (1971), partly because the profession did not have the instruments for modeling forward-looking expectations. At the time, Adaptive Expectations, a backward-looking scheme, was in vogue. It was employed to model inflation expectations. Thus, inflation expectations at time $t$ were assumed to be a function of the path of inflation prior to $t$, weighted by a factor that declined geometrically with the distance between time $t$ and the time of the inflation realization. The rate of decline was determined by a parameter that I will denote by $\gamma>0$, such that the larger is $\gamma$, the steeper the decline of the weighting factor. Cagan (1956) showed, in the context of a simple monetary model, that there is a critical $\gamma=\bar{\gamma}$, such that if $\gamma>\bar{\gamma}$, the system becomes unstable. This implies, for example, that if the economy starts off steady state, it is possible for the model to generate hyperinflation even though money supply is constant over time! This counterfactual implication led to the conclusion that the RE approach was incompatible with realistic monetary models, because RE were identified with the case in which $\gamma \rightarrow \infty$. This is, of course, wrong because no matter how large is the weight given to very recent observations, it does not make adaptive expectations rational: they are doomed to be backward looking! It is interesting to note, though, that it took around fifteen years and the RE revolution to get rid of this error (see Sargent and Wallace (1972)). ${ }^{3}$ This episode should send a warning to the profession because it shows, in an emphatic manner, that formal models can be dangerously misleading if they are not disciplined by a good dosage of common sense.

III.2. Inflation Stabilization and Incredible Reforms. In the 1980s several EM exchange-rated-base stabilization programs failed to achieve their objectives (see Kiguel and Liviatan (1994) and Little et al (1993)). An unwanted side effect was a large real currency appreciation accompanied by consumption boom and large current account deficits. This took policymakers - and the profession at large - by surprise, because according to the, then, prevalent conventional wisdom - much based on DM experience - inflation stabilization is associated with a slump in economic activity. The opposite happened. Disconnect between conventional wisdom and practice was dramatic and, as it happens in these occasions, brought to the surface a myriad of lightweight and even opportunistic comments. Neoclassical theory and "monetarism" were easy targets, but an answer from the beleaguered

2 These ideas were developed at the International Monetary Fund, and helped to make debt indexation and maturity part of IMF program design. See Guidotti and Kumar (1991) and Calvo (1991).

3 This does not invalidate the relevance of Adaptive Expectations. In fact, they can be useful complements to Rational Expectations, see Sargent (1999). 
camp did not take long to come. It relied on the assumption that these stabilization programs were likely imperfectly credible. The analysis is very simple thanks to the RE revolution. Calvo (1986 b) shows, for example, that if the public expects that the stabilization program will eventually be abandoned and high inflation stages a comeback, it might be rational for the public to anticipate consumption, which obviously enlarges the current account deficit and, under normal circumstances, lowers the real exchange rate (i.e., the relative price of tradable with respect to nontradable goods). The model assumes that the total cost of consumption includes the purchase price plus the cost of holding money in advance to carry out the transaction (i.e., Clower (1967)). The latter is an increasing function of the nominal interest rate, which rises with expected inflation, and makes the total cost of consumption is expected to be higher after the program is abandoned. Intertemporal substitution trivially follows and gives a rationale for the consumption boom. For a recent version of the model, which can accommodate the usually sizable consumption booms, see Buffie and Atolia (2012). ${ }^{4}$ The argument would also go through if inflation increased the cost of credit as a result of high price volatility, for example. ${ }^{5}$

This model can also be employed to study the impact of temporary trade liberalization (see Papageorgiou et al (1991)). Consider the case in which the government announces that trade tariffs will be permanently eliminated, but the public believes that they will eventually be reestablished. As in the monetary example, this amounts, in the mind of the private sector, to making tradable goods cheaper "today" relative to "tomorrow." Calvo (1986 b)), for example, shows that this brings about a current account deficit that would not take place if the government's announcement was fully credible. Moreover, the implied intertemporal substitution is Pareto inefficient, because it is based on an intertemporal distortion. Even if the government does not intend to abandon trade liberalization, lack of credibility brings about the same deleterious effects. The government could disappoint expectations by never reestablishing trade barriers, but that will not undo the damage! This is, thus, a glaring example of the power of credibility for the success or failure of economic reform, a phenomenon that I coined in the (tongue-in-cheek) phrase "Incredible Reforms" (see Calvo (1989 c)).

An implication of these models that policymakers should take into account is that lack of credibility could give rise to short-run effects that might give the impression that policies are highly successful. For example, the consumption boom that follows

${ }^{4}$ Calvo and Drazen (1998) extend the basic model to account for uncertainty about the duration of policy announcements.

${ }^{5}$ Sargent (1981) is closely linked to this literature. It makes a strong case for credible stabilization programs. However, the paper focuses on short-lived astronomic inflation episodes that could hardly be called "chronic." Moreover, it seems unlikely that individuals believe in the sustainability of hyperinflation, which would tend to enhance the credibility of any reasonable stabilization program and, thus, its effectiveness. 
the announcement of an exchange-rate-based stabilization program brings about an increase in the demand for money, which gives rise to larger international reserves. If the program is prompted by high inflation, these developments are likely to be interpreted as stemming from greater trust that those in charge are serious and able to carry out the necessary reforms.

It is worth noting that the deleterious effects of lack of credibility highlighted here depend on the existence of intertemporal trade, e.g., credit. Without this channel, the economy would not benefit from intertemporal trade geared to the fundamentals stressed by conventional trade theory, but, on the other hand, the economy would be free from credibility distortions. Thus, these types of models are especially relevant for EMs that have access to financial markets but have not succeeded in developing resilient market-friendly institutions. Depending on the circumstances, the model may justify imposing controls on capital mobility, for instance. But a major contribution of this literature is to highlight the relevance of expectations' management and, above all, ensuring policy credibility. ${ }^{6}$

III. 3. Expectations Dominance. Chronic inflation is typically associated with Fiscal Dominance, i.e., a situation in which the central bank loses control on money supply because it is forced to finance the fiscal deficit by issuing domestic money (as in Section III.1). The phenomenon is especially relevant when the central bank faces a recalcitrant fiscal authority that, say, for political reasons, is not willing to lower the fiscal deficit. But (what appears to be) Fiscal Dominance can also arise in an analytically much more interesting situation in which the fiscal authority is fully committed to support the inflation stabilization program, as announced.

This is illustrated in Calvo (1998), which was motivated by trying to understand why Brazil struggled to stop high inflation when public debt and the primary deficit were not grossly out of line. Let $b, \pi$ and $\pi^{e}$ denote real public debt, one-period public forward-looking inflation and expected inflation, respectively. For simplicity, I will assume that, at RE equilibrium, the real one-period interest rate is equal to zero. Thus, under risk neutrality, the equilibrium interest rate will equal expected one-period inflation, $\pi^{e}$, in which case next-period debt service bill (including amortization) in real terms equals

$$
b \frac{1+\pi^{e}}{1+\pi} .
$$

Therefore, given the rate of inflation, the larger is expected inflation, the larger will be the real debt service burden. For simplicity, let us assume that the government is bound to service debt in its totality at the end of next period and that the central

${ }^{6}$ The consumption boom phenomenon associated with stabilization programs received a lot of attention. Some outstanding alternative explanations do not rely on imperfect credibility but on a combination of lower nominal interest rates, as a result of lower inflation expectations and sticky prices. See, e.g., Rodriguez (1982). 
bank is obliged to rebate seigniorage to the private sector in the form of lump sum subsidy (so that seigniorage net of rebate equals zero). The government is assumed to manage the rate of inflation, $\pi$, by manipulating the rate of devaluation. Thus, for instance, if output is homogeneous and there are no barriers to trade, and international prices are constant in foreign exchange, it follows that inflation equals the rate of devaluation, i.e., $\pi=\varepsilon$, where $\varepsilon$ stands for the rate of devaluation.

Under the above assumptions, expression (1) denotes the real tax revenue necessary for debt service. I will assume that the fiscal authority can comfortably generate tax revenue to service its debt if $\pi=\pi^{e}$, but not a cent more. ${ }^{7}$ It follows that the government will have to default if it sets $\pi<\pi^{e}$ and, if default is too costly, it will be forced to make $\pi \geq \pi^{e}$, and become hostage of inflation expectations. For the casual observer, this would be a case of Fiscal Dominance but, in essence, the situation is better characterized as a case of Expectations Dominance, which becomes effective through the credit channel. Notice that across RE equilibriums in which $\pi=\pi^{e}$ investors get the same revenue. Hence, if the economy generates inflation higher than the government's target, the solution is Pareto inefficient. This problem holds even in a world of Rational Expectations, in which individuals are fully aware that the government's inflation target is feasible if expectations are equal to the target. In this case, however, Rational Expectations depend on beliefs about market expectations. A single individual has no command on the latter, and rationally aligns her expectations to the expectations of others, a phenomenon that the GT calls "expectations of expectations."

An interesting implication of the above example is that RE equilibrium may be validated, not because individuals are rational, but because policymakers are forced to corroborate individuals' expectations!

Calvo (1988) also shows that the problem would go away if the interest rate on government bonds were indexed to the rate of inflation. In terms of the above example, it is clear that if the rate of interest ex post was set equal to the realized rate of inflation, the government would be able to implement the target inflation rate, independently of market inflation expectations! ${ }^{8}$ This rule has been adopted in Chile through the UF (Unidad de Fomento) and may have helped to support inflation targeting. Moreover, there seems to be wide consensus that eliminating inflation uncertainty in financial contracts has helped financial deepening and the development of the mortgage market (Fontaine (1996), Shiller (1998)). In other instances, e.g., 1989 Bonex plan in Argentina, Expectations Dominance led to denominating financial contracts in terms of USD. In the simple model developed

${ }^{7}$ In Calvo (1988) government is allowed to collect higher tax revenue.

${ }^{8}$ In practice, inflation indexation is applied with a lag. This may make indexation less effective for shielding investors from inflation risk, especially during periods of high and accelerating inflation. Moreover, financial indexation may lower policymakers' incentives for price stability. 
here, USD indexation gives similar results, but this would not be the case if one allows for the existence of nontradable goods, for example.

Expectations Dominance can also have a deleterious effect on the private sector. For example, if the economy comes from high inflation and people have structured their contracts on the expectation that inflation will continue unabated, a cold turkey stabilization program, which stops inflation in its tracks, will cause the same kinds of problems highlighted above. At one point in the 1980s, for example, Brazil inflation was about 30 percent per month. Imagine the impact of lowering inflation to single digits, annually! Several stabilization programs had to be abandoned because keeping the course meant sky-high ex post real interest rates that would wreak chaos in the financial sector and the payments system. This phenomenon has been recently discussed in Lara Resende (2016). It bears some resemblance to Irving Fisher's (1933) Debt Deflation. The latter, inspired by the Great Depression, is a case in which the real value of debt skyrockets as a result of a sharp and unexpected fall in the price level (in the Great Depression wholesale prices fell by more that 30 percent). In contrast, the harmful effects of cold turkey stabilization highlighted here would arise even though prices do not fall and may continue rising, albeit at a sharply lower rate than expected.

These problems are akin to what is called "peso problem," an expression popularized in the 70s and 80s as Mexico's interest rates exceeded the rate of devaluation by a wide margin (Lewis (2016)). An explanation that, in a way, foreshadowed RE was that the phenomenon was triggered by the expectation that Mexico's peso would exhibit a maxi-devaluation. This type of devaluation involves isolated jumps in the exchange rate. Thus, interest rates will look "too large" over stretches in which the exchange rate is constant. The peso problem is indeed very close to the example discussed above. However, in Calvo (1988) the authorities are forced to validate devaluation expectations, despite the existence of another more benign RE equilibrium. The latter has important policy implications because, for instance, it highlights the relevance of indexation for stopping high inflation, even though policymakers are fully credible. Notice that these implications would be missed in models displaying equilibrium uniqueness, a feature that policy-oriented macro models tend to favor. ${ }^{9}$

So far, the discussion has abstracted from debt default. A government that is adamant on stabilizing inflation but is facing high inflation expectations may entertain the idea of default. This case is analyzed in Calvo (1988) and further developed by Corsetti and Dedola (2016). A sketch follows.

9 The literature also abounds on backward looking "wage indexation" as a factor preventing speedy price stabilization. Although this could be reinterpreted as a case of backward-looking expectations, I will refrain for discussing this issue here, given this paper's emphasis on Rational Expectations. 
Debt default can be analyzed in the context of a non-monetary economy employing the framework developed above. I will reinterpret inflation, $\pi$, and inflation expectations, $\pi^{e}$, as rate of default and expected rate of default, respectively. In this instance, the expectation that the government will default would force the government to default. In contrast to the inflation example, solving this problem is likely to be more difficult. In the inflation example, the problem could go away by adopting new types of contracts (i.e., indexation). This is less likely to work if default is in the cards, because the private sector may be less predisposed to believe the government will honor its contracts. Therefore, to improve the situation it may be necessary to bring in independent parties that are willing and capable to credibly insure investors against sovereign default. This is not easy, given the legal privileges enjoyed by sovereign states. But it seems to have worked in the Eurozone. Worried about the high interest rate premium in satellite Eurozone economies, reflecting investors concern about the solvency of those economies, Mario Draghi, President of the ECB, gave a speech on July $26^{\text {th }}, 2012$, pledging to "do whatever it takes" to lower those interest rates. This was read by the market as an ECB commitment to purchase as much of those sovereign debt instruments as necessary to squash their risk premium to default-free levels. It resulted in an astonishing fall in those rates of interest, as predicted by the model. Why can the ECB muster such an impressive muscle is an important issue. A common conjecture is that Germany is the actual credible Lender of Last Resort in view of Germany's strong fundamentals. But another conjecture that cannot be dismissed is that the ECB can print credible liquidity. I will revisit that issue in Section IV.

Once again, intertemporal trade and non-state-contingent financial contracts are at the heart of these problems. Fortunately, there is room for policy, as illustrated by the Chile and ECB experiences mentioned above.

Remark 2. Staggered Prices. Calvo and Végh (1993) extended the credibility discussion to the case in which prices are set in advance in a staggered uncoordinated manner à la Calvo (1983). Results are in line with the above analysis but the richer environment helps to show that, for instance, a non-credible inflation stabilization program faces an additional powerful challenge. If agents fail to be persuaded that authorities have the determination and public support to carry out the program, prices may continue rising at a high rate despite tight monetary policy.

Calvo and Végh (1993), taken at face value, implies that controlling inflation might become easier if prices/wages were flexible. However, this conclusion, which enjoys widespread appeal among policymakers, would be hasty. Section IV will argue that staggered prices could play a fundamental role in a monetary economy. They could provide a stable output anchor to fiat monies and units of account, without which a monetary economy may become unstable, unless the currency is credibly anchored (not necessarily pegged) to a resilient foreign currency, e.g., the USD. This is common practice in EMs (see, e.g., Calvo and Reinhart (2002)), but 
credibility usually calls for large and costly holdings of international reserves (see Calvo et al (2013)).

\section{Sudden Stop, Chronic Deflation and Sluggish Recovery: Liquidity Explanations}

The discussion in the previous section was framed in terms of conventional macro theory under the assumption of Rational Expectations. Until recently, the corresponding models were taken with a high degree of confidence by policymakers. However, amid that placid scenario, the Great Recession rose with shattering force, putting into question everything, from Rational Expectations to the feasibility of capitalism. Minsky's (2008 a) nightmares could no longer be discounted!

In this Section this paper will start to explore the new issues by giving "liquidity" a more central role than it had in mainstream macro theory prior to the Great Recession. Otherwise, however, the models stick to the assumption of Rational Expectations and other assumptions of traditional economic theory. This smoothens out the transition from the previous Section but the reader must be prepared for a sharp turn, because the new vistas that the liquidity approach conveys are anything but ordinary.

"Liquidity" is an issue that only recently has been given serious attention in the literature (see, e.g., Holmström and Tirole (2011), Calvo (2016)). This situation may be partly due to the fact that mainstream models appeared to be adequate for monetary policy before the Great Recession, at least for DMs. But I would not discard the possibility that model-builders were reluctant to focus on liquidity issues because they cannot be easily accommodated in canonical general equilibrium models. In other words: intellectual inertia.

This section will argue that liquidity offers promising insights but we have to make sure that we are walking on firm grounds. Although liquidity has become a ubiquitous word, "fashion over substance" seems to dominate. For example, several observers claim that the Lehman 2008 crisis involved a phenomenal Liquidity Crunch on financial assets backed up by real assets, e.g., ABS. And they seem undisturbed to say, in the same breath, this shock was accompanied by a flight to quality involving the USD, a fiat money. Something is amiss here, and forces us to delve into the reasons for fiat money to hold positive value in terms of output, a characteristic of fiat money that conventional macroeconomics tends to take for granted.

Section IV.1 considers Frank Hahn's (1965) fundamental observation that, as a general rule, conventional general equilibrium monetary models cannot rule out the existence of barter equilibria. This result makes the flight-to-USD phenomenon even more puzzling, and enhances the relevance of finding plausible explanations for the resilience of money. The flight-to-money phenomenon was a central issue in 
Keynes's GT (and it is associated with what was elsewhere called Liquidity Trap). ${ }^{10}$ In an isolated and wholly ignored paragraph, the GT puts forward a simple, but in my opinion insightful, conjecture that I labeled the Price Theory of Money (PTM). ${ }^{11}$ The PTM claims that money derives its liquidity and positive purchasing power from the existence of staggered prices. Staggered prices provide an output backing to money that, as a general rule, governments fail to give. Notice that this output backstop does not extend to other liquid assets with flexible nominal prices.

While staggered prices give a real platform for liquidity of money that helps to explain its resilience during financial crisis episodes, this does not rule out liquidity fragility or liquidity shortage - because money's output backstop is anything but ironclad. This leads naturally in Section IV.2 to consider a world with multiple monies and a variety of nominal liabilities, e.g., Asset-backed securities, EM USDdenominated bonds. Under these conditions, resilient and fragile liquid assets live next to each other. Since, by definition, liquid assets are transactions facilitators, Liquidity Crunch of a subset of liquid assets generates a sudden deceleration of transaction flows that rely on those assets. In practice, this takes the form of credit Sudden Stop - i.e., large and largely unexpected fall in credit flows - that could become systemic, given that liquidity is in the eye of the beholder. ${ }^{12}$ These insights can also be employed as a guide for monetary policy. It can be shown, for instance, that standard open-market operations could be ineffective for restoring potential output - and that the latter may be better served by unconventional monetary policy instruments, which do not call for lowering the central bank's policy interest rate.

Section IV.3 will focus on the case in which the official sector is unable to increase the stock of real liquidity. This could be the result of having increased liquid public debt far beyond its output backing. I will show that this situation may generate Chronic Deflation. Finally, Section IV.4 will argue that liquidity shortage can also help to rationalize "Sluggish Recovery" (aka "Secular Stagnation").

10 I conducted a search in a Kindle edition of the General Theory and could not find the expression "liquidity trap."

11 See Calvo $(2012,2016)$.

12 As noted in the Introduction, Sudden Stop is an expression introduced to refer to severe contraction in international capital flows. The phenomenon has also being observed in Europe during the Great Recession (see Merler and Pisani-Ferry (2012)). Nowadays it has been extended to credit flows. To avoid confusion, I choose to dub them "credit" Sudden Stops. 


\section{1. Hahn's Problem, the Price Theory of Money, and Fear of Floating}

The typical mainstream macro model assumes that there exists an object called money - usually denoted $M$ - that provides liquidity services. A popular assumption in the literature is "cash-in-advance," according to which, in order to conduct market transactions, agents have to bring to market a quantity of $M$ proportional to the monetary (or nominal) market value of planned purchases (e.g., the Clower (1967) constraint). In simple models, the proportionality coefficient is assumed to be constant. Despite its simplicity, the cash-in-advance assumption dramatizes an important fact that is easily ignored in nonmonetary economics, namely, that liquidity services are essential for trade. In this setup, if $M=0$, no trade is possible!

Let planned purchases be denoted by $c$ (in terms of homogeneous real output), and the real (or output) price of money (i.e., the inverse of the price level) by $\Gamma$, then, setting the factor of proportionality $=1$, the cash-in-advance condition can be expressed as:

$$
M \Gamma=c .
$$

Thus, as pointed out above, in equilibrium, if $M=0$, then $c=0$, and there cannot be trade. But, what if $\Gamma=0$ ? Clearly, the result is the same: agents will be doomed to operate under full autarky. Is $\Gamma=0$ a possible equilibrium outcome? Hahn (1965) shows that it is. The proof is trivial if $M$ has no intrinsic market value, because in that case money cannot buy output and the situation is equivalent to bringing no money to the market! ${ }^{13}$ This is a deep observation that does not apply to regular goods: if the price of bread is zero in terms of other goods, say, there is likely to be excess demand for bread.

There have been attempts to show conditions under which zero-output value of money can be ruled out; for example, assuming that real monetary balances, i.e., $M \Gamma$, enter utility functions, that satisfy Inada-type conditions. ${ }^{14}$ These conditions sound somewhat artificial in this case and, moreover, I do not think they are enough to rule out $\Gamma=0$. For, if the latter holds, then $M \Gamma=0$, independently of how large is $M$. No matter how valuable would monetary balances be for individual agents, there is nothing single individuals can do to make $M \Gamma>0$. In fact, as noted in footnote 12 , if holding worthless $M$ involves just a minor nuisance, agents would dump $M$ even though they are starving for $M \Gamma>0$ !

The GT offers a conjecture for why $\Gamma>0$. In short, the conjecture is that $\Gamma>0$ because agents employ nominal prices to communicate to the market the quantity of

13 Notice that if holding $M$ were a minor nuisance, its demand would be nil, causing excess supply in the money market. However, by Walras Law, that does not generate excess demand in the rest of the economy because the real price of money $\Gamma=0$.

14 See Obstfeld and Rogoff (1983 and 1986). 
units of account (money, in this case) at which they are ready to sell their staples and, moreover, they are prepared to keep those prices 'live' for some interval of time. Hence, nominal prices come first: we are in the world of "prices-in-advance." For an individual agent to have incentives to set her price in advance, it helps that a substantial number of other agents have already posted their prices in similar fashion, and that most of those prices can be taken for granted by present price setters. This is, thus, also a world of "staggered prices." In this world, individual price setters have a clear reference when setting their prices in terms of money because at time $t$, say, $\Gamma_{t}$ is (essentially) predetermined and positive. ${ }^{15}$ Moreover, keeping their price quotations 'live' for a period of time does not involve great risks of price misalignment if the expected rate of inflation is low. ${ }^{16}$

The PTM can be criticized for being no more than a tautology: $\Gamma>0$ because $\Gamma>0$. But the case is subtler. The PTM states: $\Gamma_{t}>0$ because $\Gamma_{t-1}>0$, and just a few agents can/will change their prices at $t$. This mechanism is incentive compatible: price setters at $t$ will have no incentives to set their money prices $=\infty$ (which is equivalent to refusing to quote their prices in terms of money). Compare this with canonical models like the cash-in-advance, or models in which real monetary balances are an argument in utility or production functions - and prices are perfectly flexible. Even if $\Gamma_{t-1}>0$, in these canonical models individuals have no incentives that would rule out $\Gamma_{t}=0$ ! Notice that the PTM does not rely on the existence of physical money. It is a theory that applies equally well to a cashless economy with a unit of account in terms of which prices are set in a staggered manner (see Woodford (2003)). To be sure, it would be interesting to explore the process by which units of account are established, but that does make canonical models superior to the PTM, because models that are anchored on $M$ instead of $\Gamma$ also need a rationale for the choice of a particular unit of account.

The PTM helps to rule out $\Gamma=0$ but does not guarantee that $\Gamma$ will be stable in realistic situations, because not all prices are set in terms of the same unit of account. ${ }^{17}$ To wit, the world displays many units of account subject to variable bilateral exchange rates. Interestingly, though, there is more stability in bilateral exchange rates than the existence of multiple of currencies would lead one to expect. For example, Calvo and Reinhart (2002) show that EMs tend to peg their currencies to so-called reserve currencies, a phenomenon called "fear of floating."

15 However, this does not necessarily imply "inflation in advance." Thus, the output backup of money will also be a function of inflation expectations, and the issues raised in Section III still apply.

${ }^{16}$ However, the risks of setting prices in advance could be large in periods in which, say, the economy is buffeted by large swings in its terms of trade, which involve prices set outside the domestic economy.

17 The PTM does not ensure uniqueness of the $\Gamma$ path even if there exists a unique unit of account. Uniqueness may require rules like Taylor rule, a central topic in New Keynesian literature. See Woodford (2003) and also Calvo (2016) for a skeptical assessment about the relevance of New Keynesian models in that respect. 
Reserve currencies are units of accounts that are employed as invoice currencies in a wide variety of international trade and financial transactions (see Gopinah (2015)). Consequently, pegging to a reserve currency strengthens EM currencies output backing, making them more reliable as stores of value, which, in turn, enhances the liquidity of reserve currencies. The USD is the king among reserve currencies, and has shown its muscle during the Lehman crisis, as the USD appreciated relative to other currencies, even though the US economy was at the epicenter of the crisis. The USD privilege is rooted on considerations that fall outside the scope of the present paper, and I will not discuss them here. However, it is worth pointing out that, especially in small EMs, the realm of their national units of account is very limited, implying that unless their currencies are pegged to a reserve currency, their currencies' output backing would be very narrow, which could make them easy targets of currency runs' episodes, and large currency devaluation or appreciation (recall the sharp and surprising appreciation of the Swiss franc in January 2015).

To make the previous statements more intuitive, it is useful to think of currencies in terms of a T-account with the stock of money on the liability side and a pot of goods (output) on the asset side. The pot of goods stands for the currency's output backing. This is similar to a bank's balance sheet with deposits on the right-hand side and illiquid loans on the left-hand side. In the present case, the pot of goods stands for the goods and services that money holders can grab in exchange for money if they wish to. The pot of goods is likely to be smaller than the output value of money, ГM. Hence, as in banking models, there may exist multiple equilibriums (see, e.g., Diamond and Dybvig (1983)). In a "good" equilibrium $\Gamma M$ could far exceed the pot of goods, while in a "bad" equilibrium $\Gamma M$ would be just equal to the pot of goods. ${ }^{18}$ Accumulating international reserves in terms of reserve currencies increases the pot of goods. It is intuitive that pegging, especially if accompanied by reserve accumulation, is likely to diminish the probability of currency runs and, thus, lowering the need for trade to rely on derivative markets, which are costly and not easily available for small- and medium-sized enterprises. This helps to give a rationale to "fear of floating" and international reserve accumulation.

It should be noted that fear of floating is not unique to EMs. During the Lehman crisis, for example, the Fed signed a large currency swap agreement with the ECB to prevent a wave of massive bankruptcies in the Eurozone (with possible spillover effects on the US), given that the Eurozone was undergoing a severe USD shortage episode. Thus, despite the large menu of national currencies, the world economy appears to be groping towards a Bretton-Woods-like scheme with the USD as the nominal (and, hence, real) anchor, and enjoying some partial Lender of Last Resort services from the Fed, especially if the US economy is part of the problem. Even the Fund, a cheerleader for floating exchange rates, has started to realize the rationale

18 Equilibria could be Pareto ranked by $\Gamma M$ in models in which $\Gamma M$ is an argument in utility and/or production functions and exhibits positive partial derivatives. 
for fear of floating, and becoming more permissive about intervention in the foreign exchange market.

\section{2. A Larger Set of Liquid Assets: Sudden Stop}

In practice, national currencies' own-rates of interest are nil. Thus, unless price deflation is rampant, there are incentives to create quasi-monies. This process goes back to at least medieval banking (see Cipolla (1989)) and ran at full steam prior to the Great Recession. The phenomenon has already been covered in multiple sources (e.g., Brunnermeier (2009)), so I will just highlight some salient features that relate to the discussion in the previous subsection. A common characteristic is that quasimonies take the form of fixed-income obligations denominated in terms of a unit of account. The age-old example is bank deposits backed up by a credible Lender of Last Resort (typically, a central bank able to print currency or public liabilities denominated in the bank deposits' unit of account). A more recent example is Mortgage Backed securities (MBS), which are large pools of mortgage contracts denominated in terms of a unit of account. Barring systemic shocks, pooling allows MBS to take advantage of the Law of Large Numbers, reducing the need for information about individual contracts, and exhibiting low return volatility in terms of the corresponding unit of account. As a result, securitized assets like MBS can come to resemble interest-bearing money.

The similarity between money and quasi-monies does not stop there. Hahn's problem also applies to quasi-monies because they are subject to runs that are akin to those discussed in the banking literature (see Diamond and Dybvig (1983) and the notes about national monies in previous section). In those models, bank deposits provide liquidity services but, unless there is a credible Lender of Last Resort, there exist other equilibriums in which a sizable share of depositors tries to get their money out of the bank at the same time, the bank goes bankrupt and the liquidity services of the associated deposits evaporate. Runs on quasi-monies can occur even though their fundamentals show no fissure prior to the run, similar to the phenomenon referred to under the Hahn's problem. Except for bank deposits fully ensured by a Lender of Last Resort, most other liquid assets have flexible prices in terms of the unit of account. Hence, if the market refuses to take them as means of exchange, their price may plunge. Prices may not go to zero because, say, MBS involve obligations that will eventually be at least partially honored, but the price fall of these securities may still be significant.

Quasi-monies play an important role as credit collateral (e.g., Repurchase Agreements or repos). They do not circulate as fiat money or bank deposits, but are important transaction facilitators for intertemporal trade transactions. Therefore, quasi-monies fall under the category of liquid assets as defined here. Positive welfare effects generated by stable liquid assets are bound to be very large, given that credit is essential for trade in modern capitalist economies. Without liquid assets it would be hard to realize gains from trade. A major problem, though, is that these assets are subject to liquidity crunch without warning and cause major 
interruption of credit flows. There is still no good understanding how liquidity crunch takes place, which leaves the credit market at the mercy of large shocks that are hard or impossible to insure against. This problem is exacerbated by the fact that, given that liquidity is only partially linked to standard fundamentals, credit crunch triggered by liquidity crunch in one corner of the market can easily spread to the rest of the economy. Thus, a local liquidity crunch episode could become systemic, a situation for which insurance markets are ineffective. This phenomenon was clear in the 1998 Russian and 2007/8 Subprime crises (see Calvo (2016)). As noted above, a large interruption of credit flows under these circumstances is called Sudden Stop, and typically cause (a) large capital loss in the financial sector and, more importantly, (b) casts serious doubts about the reliability of liquid assets. The latter, in particular, contributes to making these crises highly persistent (see Reinhart and Reinhart (2010), Calvo (2016, Chapter 6)). The Great Recession is a telling example.

The above observations were not central to the DM policy discussion prior to the Great Recession. Rather, the opposite view prevailed. There was wide consensus that DM financial system ran as clockwork driven by the hand of sophisticated operators (see NYT (2008)). And, moreover, if crisis erupted, the view was that reserve-currency central banks could rapidly stabilize the situation by lowering their interest rates just a few basis points. This view was partly based on Friedman and Schwartz (1963) highly influential conjecture that the Great Depression would have been a regular US recession if the Fed kept the price level from plunging (e.g., in the Great Depression the WPI fell by more than 30 percent, peak to trough). Unfortunately, the Great Recession put a question mark on the Friedman-Schwartz conjecture. The Fed and other reserve-currency central banks followed the advice, price-level deflation was avoided and, yet, this did not prevent a deep and long lasting recession. In the Eurozone, for example, GDP has not (as of April 2016) recovered its level prior to the Lehman crisis. To be sure, the evidence suggests that monetary expansion was helpful, perhaps because it partially prevented a replay of I. Fisher (1933) Debt Deflation, ${ }^{19}$ but results are much worse than expected. What is missing? The above discussion offers a clue: central banks' liquidity does not necessarily solve liquidity problems triggered by Liquidity Crunch, unless such liquidity is directed to restore the market for liquid assets hit by crisis (see Calvo (2012)). Without that, credit flows stop and can cause major damage. Liquid assets are not born equal, indeed!

DM central banks became aware that something was seriously amiss when they hit the Zero Lower Bound, and adopted policies aimed at unclogging the credit channel in a more direct fashion. It took the form of Quantitative Easing (QE), e.g., central bank purchases of MBS, and measures that directly stimulate credit to the private sector. The ECB, for example, has announced a modus operandi on March 7, 2016, that, among other things, expands the scope of a liquidity window for some

${ }^{19}$ However, the Fed did not prevent Debt Deflation in the housing market where dollar prices fell by around 30 percent. 
corporate bonds, and de facto subsidizes loans to the private sector. All of this is consistent with the view that Liquidity Crunch calls for heterodox central bank policy which, incidentally, is dangerously close to being catalogued as a surreptitious form of fiscal policy.

Remark 3. Some microfoundations. To clarify the discussion, let us consider a simple case in which there is an asset-backed security, which underlying asset I will identify with "land". Land, denoted by $k$, is in fixed supply and subject to no maintenance costs. Output is a function of land as a standard factor of production but, in addition, land is a transactions facilitator for firms; land's liquidity (measured in terms of output) also has a positive effect on output. Hence, I will assume that output is given by $f(k+\theta q k)$, where $q$ and $\theta$ are the output price of land and a liquidity coefficient, respectively; $\theta$ is between 0 and 1 . Let the real interest rate (i.e., the own-interest rate on output) be denoted by $r$. Then, at a steady state in which $q$ is expected to be constant over time, profit maximization at $k>0$ implies the following first-order condition with respect to $k: f^{\prime}(k+\theta q k) \theta=r$. One can show that if function $f$ is Cobb-Douglas, the price of land $q$ rises with the liquidity coefficient $\theta$. Hence, a liquidity crunch on land could bring about a collapse in the relative price of land with respect to output. In this simple setup, money supply has no role to play. Therefore, if the price of land causes side effects like unplanned over-indebtedness, standard monetary policy cannot help. One needs instruments that can have an impact on $q$. The unconventional purchase of 'toxic' assets, as in the US QE1, is a possible, albeit not foolproof, example. ${ }^{20}$

As noted above, Liquidity Crunch is no DM monopoly. The systemic EM crises in the 1990s can also be characterized that way. But there are important differences. Consider the 1997/1998 Asian/Russian crises, which involved a run against EM bonds floated in the international capital market. First and foremost, unlike in DMs, those bonds were denominated in USD or other reserve currency, not EM domestic monies. The meltdown could have been prevented by a massive purchase by EMs using international reserves, or drawing on credit lines from an International Lender of Last Reserve (e.g., the IMF). But the latter was not available, and EMs had neither the resources (i.e., international reserves) nor the ability to launch a coordinated counteroffensive. Therefore, this gave rise to a Sudden Stop episode that, employing the metaphor in Subsection IV.1, lowered the pot of goods backing up domestic money and triggered currency devaluation, not appreciation - in sharp contrast with the US during the Lehman crisis. Furthermore, currency devaluation weakened EM balance sheets, because foreign-currency-denominated debt is partly employed to fund projects denominated in domestic currency. Thus, large devaluation - a hallmark of EM Sudden Stops - brought about harmful effects that are akin to I. Fisher Debt Deflation, as the value of debt obligations skyrocketed relative to the flow of domestic currency revenue, exacerbating the depth of the

${ }^{20}$ These issues are discussed in greater detail in Calvo (2012) and Calvo (2016, Chapters 3 and 5). 
financial crisis. Clearly, high initial debt and low levels of international reserves enhance the severity of the crisis. These conditions prevailed prior to the Russian crisis because, in my opinion, few investors and policymakers foresaw the massive systemic meltdown that was going to occur in the Russian crisis.

Interestingly, after the Asian/Russian crises, favorable circumstances that gave rise to improving current account balances and large accumulation of international reserves in several Asian and Latin American economies placed those economies on a stronger footing to face the 2008 Lehman crisis (see WEO (2010)). The shock was felt but recovery was fast, and was followed by a string of relatively high growth rates, which suggests that the size of the "pot of goods" makes a difference. This is also borne out by empirical research (see Calvo, Izquierdo and Mejía (2016), Calvo, Izquierdo and Loo-Kung (2013), and Calvo (2016)).

As argued in Subsection IV.1, "fear of floating" could be traced back to an attempt by EMs to anchor their currencies on reserve currencies. This works for regular shocks but it is probably too costly to prevent currency runs in a Sudden Stop episode. Still, sizable international reserves could help to contain runaway inflation. The reason is simple: employing the metaphor in Subsection IV.1, devaluation increases the nominal value of the asset side of the balance sheet (the "pot of goods"), without, in principle, changing the supply of money. Therefore, money's output backup becomes stronger and gives the central bank more ammunition to stop inflation from spiraling. On the other hand, it is easy to show that if the central bank intervenes and stops devaluation in its track, money's output backup would weaken, in the normal situation in which monetary domestic liabilities exceed international reserves. This helps to explain why during the recent sizable contraction of capital flows to EMs, many countries in Latin America decided to meet the shock with large devaluation and only modest sacrifice of international reserves. Spiraling inflation, the nemesis of these economies in the 1980s, has not been a major problem (see WEO (2016)).

Remark 4. Endogenous Liquidity: Currency Substitution. Liquid assets have a long history in which tyrants and wars play a major role, but also liquid assets owe their existence to much more friendly technical change and run-of-the-mill incentives. EMs are a rich laboratory that illustrates that high inflation, for instance, can give rise to the creation of local liquid assets in the form of foreign currencies, a phenomenon labeled "currency substitution," (see Calvo-Végh discussion in Calvo (1996)). Foreign currencies in question are typically reserve currencies, but need some help from domestic agents to become liquid at the local level. Incentives for the creation of liquid assets or arrangements can also take very different forms. Gorton and Metrick (2012), for instance, claim that Shadow Banks were partly prompted by attempting to offer more reliable deposit insurance arrangements for large depositors, like pension funds. 
The topic of endogenous liquidity is still in its infancy. The currency substitution literature called attention to some constraints that the phenomenon imparts on monetary policy, but I feel that the literature has scarcely scratched the surface. Taking an approach similar to that of the micro banking literature (e.g., Diamond and Dybvig (1983)), for instance, suggests the existence of sharp discontinuities or non-linearities that I do not think have been fully exploited in the currency substitution literature. Moreover, a better understanding of endogenous liquidity could help to get a more solid grasp about the implications of low reserve-currency interest rates, a highly topical issue. This type of theory may help to rationalize the commonly heard statement that low international interest rates are spawning EM fragile liquid assets that are subject to costly runs.

\section{3. The Deflation Cycle: Chronic Deflation}

Price deflation has pushed out Chronic Inflation from center stage, and issues from the distant past like Liquidity Trap have come back with a vengeance. Thus, momentarily at least, the voluminous inflation literature will be swapped for oldfashioned deflation papers, and a few essays by economic historians of the Great Depression. It is worrisome, though, that past deflation episodes occurred under very different circumstances and data is scant. Moreover, although Chronic Deflation could be partly explained by over-indebtedness and balance sheet problems (e.g., Koo (2009)), these problems could well have arisen in an hyperinflationary context, highlighted in Sargent (1981). This motivated me to try alternative explanations.

In this subsection, I will explore a tentative road inspired by the PTM. The basic idea is straightforward. Consider an economy in which (fiat) money is the only liquid asset. Money enjoys some output backup thanks to the existence of sticky prices. Doubling the stock of money supply in that context, doubles real monetary balances - but it does not necessarily double money's output backup. If money's output backup stays constant, for instance, the expected purchasing power of money may less than double. In Calvo (2016) I call this effect Liquidity Deflation. It is tantamount to a pecuniary externality for atomistic agents. The initial doubling of money supply may make people feel that their monetary wealth has doubled in real terms, but they will soon be disabused as they realize that they would have to share money's output backup with the rest of the agents, even if prices are sticky.

It is interesting to compare the above situation to the conventional one in monetary theory, in which individuals assess money's liquidity services by their individual holdings of real monetary balances. Suppose, for simplicity, that prices are flexible and the demand for the liquidity of real monetary balances is constant. Hence, in the conventional model, doubling money supply, will double the equilibrium price level. In contrast, if Liquidity Deflation is at work, prices may less than double. Therefore, Liquidity Deflation gives a rationale for the difficulties central banks may find in stopping deflationary forces by expanding their balance sheets. This 
reasoning applies with special force for reserve currencies, for which it is difficult to find more reliable alternative liquid assets. Formal details follow.

To stay on familiar grounds, I will start focusing on the Pigou effect, a pivotal concept for the 'classicals' (as defined in the GT) argument against the relevance of Liquidity Trap, who argued that wage and price flexibility could help to restore full employment. Formally, the argument is that the liquidity of real monetary balances, $M \Gamma$, rises without bound as the price level falls, i.e., as $\Gamma$ rises. Under normal circumstances, the associated wealth effect will lift aggregate demand (this is the Pigou effect), a process that will not stop until full employment is restored. This argument ignores I. Fisher (1933) Debt Deflation, but I will not let this distract us because the main point is to show that the argument could be fallacious nonetheless.

The Pigou effect relies on the assumption that economic agents will take $M \Gamma$ as a highly reliable yardstick of how much output can be fetched in the market by exchanging $M \Gamma$ for output, even in cases where aggregate $M \Gamma$ exceeds by a large margin total non-monetary wealth. This assumption is consistent with individual rationality under the assumption that there is no run against money. The latter may not sound as a strong assumption for the US dollar, but runs cannot be discounted if $M$ contains quasi-monies, even if the latter are indexed to the US dollar (as illustrated by Asset Backed securities' meltdown in the Lehman crisis, see Gorton and Metrick (2012)). Thus, if runs are in the cards, it is plausible to argue that, beyond a certain point, an increase in $M \Gamma$ may be equivalent to less output in case of a run, as individuals rush to exchange money for output and take advantage of price stickiness, while it lasts (recall the metaphor in Subsection IV.1). Therefore, agents that take runs into consideration will attach a liquidity coefficient to $M \Gamma$, which is less than unity. This corresponds to the Liquidity Deflation effect mentioned above. Following these lines, I will assume that the liquidity of money for a single individual is given by the expression:

$$
M \Gamma+Z\left((M \Gamma)^{e}\right), Z^{\prime}<0,
$$

where $(M \Gamma)^{e}$ stands for equilibrium aggregate real monetary balances, and function $Z$ captures Liquidity Deflation. This is equivalent to assuming that it is rational for a single individual in an atomistic environment to take her own $M \Gamma$ as real wealth, but adjusts liquidity services of money downwards as a function of aggregate $M \Gamma$. Liquidity Deflation opens the possibility that the expansionary effect of a larger stock of real monetary balances fizzles out as monetary balances become large.

To couch the discussion in more familiar terms, consider the cash-in-advance equation (1), and stick on the left-hand side the new definition of liquidity services from equation (2). Since in a Rational Expectations equilibrium with a representative individual $(M \Gamma)^{e}=M \Gamma$, we get

$$
M \Gamma+Z(M \Gamma)=c .
$$


Clearly, it is now conceivable that the Pigou effect is nil, because the wealth effect is offset by the negative liquidity effect. Hence, a fall in the price level, or an increase in money supply, given the price level, could have no effect on aggregate demand. Suppose, for example, that real liquidity hits the upper bound and the associated aggregate demand is below full capacity output. This would tend to depress the price level, which exacerbates liquidity deflation - lowering money's output backup, and eventually triggering a run against $M$ that destroys money's liquidity. Notice that the failure of the Pigou effect - and the resulting Liquidity Trap - highlighted here is due to supply-side considerations. I will call it "Supply-Side Liquidity Trap." This is radically different from the GT rationale, which relies on the assumption that the demand for money is infinitely elastic with respect to "the" interest rate. It is worth noting, though, that GT Liquidity Trap and Liquidity Deflations are complementary rationales for situations in which increasing money supply has a hard time stimulating output.

Remark 5. ECB Puzzle. At the end of Section III.3 I referred to the highly successful ECB strategy for lowering risk premiums on some Eurozone sovereign bonds, which consisted in announcing that the bank "would do whatever it takes" to achieve this objective. Given the small ECB capital relative to the stock of sovereign bonds from vulnerable economies, e.g., Italy, Spain, a popular and plausible conjecture is that success of the strategy stems from the expectation that Germany would bail out the ECB if necessary. This conjecture is in accord with the above discussion because Germany would be providing the "pot of goods" behind the ECB liabilities. It is interesting, though, that in $2007 / 8$, when the Great Recession reached a boiling point, the actual lender of last resort happened to be the Fed! The Fed's comparative advantage over Germany under those circumstances was its capacity to "print" USD, an asset towards which the whole world was running for safety. This suggests that even though the ECB was very successful in lowering risk premiums in the Eurozone, it may again need the support of the Fed if, for instance, the Federal Funds rate rises faster than expected. Thus, it would be a mistake to think that the euro is runs-free, simply because the ECB was able to lower risk premiums. This implies that the assumption behind Liquidity Deflation above is not vacuous, even in the case of a reserve currency like the euro.

Remark 6. More on supply-side Liquidity Trap. The above results may look confusing to those familiar with the standard approach in monetary theory (see, for instance, Patinkin (1965)) where individuals internalize the pecuniary externalities introduced in expression (2). Thus, if one follows the standard approach, the cashin-advance constraint would take form (3) above. Let $\overline{M \Gamma}$ denote the value of real monetary balances that maximize $M \Gamma+Z(M \Gamma)$. If $\overline{M \Gamma}$ is not large enough to generate full capacity utilization, the situation would be one of "real money shortage." But it would not correspond to Liquidity Trap, because an increase in money supply will paradoxically generate excess supply of money and, if nominal prices are upward flexible, it would result in a fall in $\Gamma$ (i.e., an increase in the price level) that pushes real monetary balances back to $\overline{M \Gamma}$. This would validate the view, 
popular among well-trained economists, that an increase in the supply of money raises nominal prices, unless GT Liquidity Trap holds and the demand for money is infinitely interest elastic.

In contrast, if the pecuniary externality is not internalized, as assumed in expression

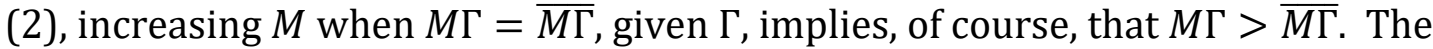
larger stock of real monetary balances $M \Gamma$ yields lower not higher liquidity services because $M \Gamma+Z(M \Gamma)$ is maximized at $\overline{M \Gamma}$, and individuals will vie for more real monetary balances - not less as implied in the standard approach. This situation, if anything, will put downward pressure on the price level, raising $M \Gamma$ even further, and driving the system into a vicious chronic deflation cycle.

An interesting extension of the model that can also help to make the new results more intuitive is to assume that $(M \Gamma)^{e}$ runs behind $M \Gamma$. Consider the following example:

$$
(M \Gamma)_{t+1}^{e}=M \Gamma_{t}
$$

which, taking equations (2) and (4) into account, implies

$$
M \Gamma_{t}+Z\left(M \Gamma_{t-1}\right)=c_{t}
$$

Hence, an increase in money supply will succeed in stimulating aggregate demand at time $t$ but money stock will have to continue rising to prevent Liquidity Deflation from catching up.

In this example, even if initially $M \Gamma=\overline{M \Gamma}$ (recall Remark 6), the central bank would be able to generate full capacity utilization by helicopter money, say, but it will have to continue doing so to prevent renewed recessionary pressures and, possibly price deflation. This is interesting because it is an example in which deflation is a persistent threat requiring an endless expansion of money supply: Pigou meets Sisyphus!

An interesting twist is to replace equation (3) by

$$
M \Gamma+Z(M \Gamma)=L\left(i-i^{m}, y\right), L_{i-i}{ }^{m}<0, L_{y}>0,
$$

where $L$ is the standard textbook liquidity preference function, and $i^{m}$ stands for the interest rate on money. The latter is a shortcut of Calvo and Végh (1995) model in which money is a mix of cash and treasury bills, and $i^{m}$ can be interpreted as the interest rate controlled by the central bank (e.g., the Federal Funds rate in the US). ${ }^{21}$

\footnotetext{
21 Technical note. The absence of the Liquidity Deflation term $Z$ from the demand
} side in equation (6) holds if derived from a standard representative-individual 
To put equation (6) through its paces, note that in the IS/LM apparatus, equation (6) corresponds to the LM curve. Thus, a rise in $i^{m}$ will increase the demand for money (i.e., shifts up the LM curve) and generate output contraction. Note that contraction holds even in the case in which $Q E$ is ineffective. This helps to rationalize the opinion, popular in current debate that QE is no longer effective, but a rise in the Fed's rate can deepen the extent of recession.

However, the impact of increasing $i^{m}$ could have the opposite sign. For the sake of the exposition, I will assume equation (4). Suppose that money (including other safe assets) has a role as a medium of exchange for firms' transactions. This can be captured by assuming that real monetary balances, $M \Gamma$, enter the production function. Let the latter be denoted by $F\left(M \Gamma_{t}+\mathrm{Z}\left(M \Gamma_{t-1}\right)\right)$, where function $F$ is strictly concave and satisfies Inada conditions around 0 . The representative firm's profit (in real terms) is given by

$$
F\left(M_{t} \Gamma_{t}+\mathrm{Z}\left(M_{t-1} \Gamma_{t-1}\right)\right)-\left(i-i^{m}\right) M_{t} \Gamma_{t} .
$$

Thus, the first-order condition with respect to $M_{t}$ is

$$
F^{\prime}\left(M_{t} \Gamma_{t}+\mathrm{Z}\left(M_{t-1} \Gamma_{t-1}\right)\right)=i-i^{m} .
$$

Hence, lowering the central bank interest rate $i^{m}$ leads to a fall in output (and the Zero Lower Bound is a non-issue), because it increases the opportunity cost of money holdings. The negative output effect from lower $i^{m}$ would also hold if money had a role as credit collateral. I find it curious that the literature and policy debate systematically assumes that "easy money" is expansionary, despite the popularity of the literature that highlights collateral assets (e.g., Kiyotaki and Moore (1997)), and the central role of collateral meltdown in the Lehman crisis (see Gorton and Metrick (2012)). ${ }^{22}$ Notice that under these assumptions maximum steady-state output is achieved at $M \Gamma=\overline{M \Gamma}$. If this output level is thought to be too low, interest rate policy alone could not help to take the economy off that rut. As in the previous case, the central bank will be doomed to rely on unconventional monetary policy in aeternum.

In sum, liquidity deflation could generate Chronic Deflation. Standard and unconventional monetary policy may fail to generate liquidity necessary to restore full employment. Moreover, as deflation proves to be much more resilient than expected, and output is dragged down by lack of aggregate demand, the private sector may start considering money an attractive investment vehicle, exacerbating price deflation. These effects will be less acute if the economy operates below $\overline{M \Gamma}$, but they may start to be felt, leading policymakers to turn their attention to alternatives like fiscal policy. This may be the right way to go. However, given

model in which $M \Gamma+Z\left((M \Gamma)^{e}\right)$ in an argument in the utility function. However, this would not hold true if the $Z$ function multiplies $M \Gamma$.

${ }^{22}$ For further discussion on this topic, see Calvo (2016). 
credit market difficulties, it would be misleading to analyze the effects of fiscal policy ignoring financial constraints. Liquidity shortage could have a major impact on the size of the Keynesian multiplier. Ilzetzki, Mendoza and Végh (2013), for instance, found that the multiplier is negative in highly indebted economies.

Remark 7. Spillover effects. Liquidity shortage and deflation in DMs could spill over to EMs, generating new liquid assets centered on EM liabilities (Gorton (2015), Calvo (2016)). For EMs that display large international reserves this situation may enhance the liquidity of public sector obligations, for example, leading to lower pass-through coefficients and making inflation targets easier to achieve. This is, in principle, good news for EMs but, as usual, there is also a dark side: liquidity of EM liabilities is likely to be sensitive to DM interest rates.

In closing, it is worth pointing out that the Supply-Side Liquidity Trap phenomenon discussed here is a close relative to the burgeoning Safe-Asset Shortage literature (see Caballero et al. 2016). Both emphasize difficulties in stimulating aggregate demand or output supply due to supply-related factors. The value-added of the approach in this paper is that these factors are linked to Liquidity, traced to the large loss of liquidity in e.g., the inception of the Great Recession, and the difficulty of increasing liquidity by pumping in reserve currency public sector liabilities, or a fall in the international (e.g., USD-denominated) price level. Moreover, the discussion suggests that Supply-Side Liquidity Trap for reserve currencies is linked to collateral trouble in the credit channel that lowers the output backstop of liquid assets, a topic addressed next.

\section{IV.4. Sluggish Recovery}

Empirical evidence shows that economies may take long to recover from severe financial crises (e.g., Reinhart and Reinhart (2010)). The Great Recession is a striking example. The EU is still struggling to recover its output peak in 2008. The US has been more successful but output is still below trend. This phenomenon has been attributed to credit boom prior to crisis and resulting over-indebtedness (e.g., Koo (2009), Reinhart and Reinhart (2010), Taylor (2015)). Naturally, theory has put financial frictions and imperfections at center stage - although, it should be noted, more as amplifiers than main triggering factors (see, e.g., Queraltó (2013)). Less attention has been paid to liquidity fragility, a birth defect of the financial sector. I am afraid that this bias may result in losing sight of some valuable "low-hanging fruits" that help to explain not only sluggish recovery, but also other central features of systemic financial crises, e.g., nominal price deflation. A model displaying those features is discussed in Calvo (2016, Chapter 5). I will sketch it out in what follows.

Consider a closed-economy, representative-agent model under perfect price flexibility. Output can be allocated on a one-to-one basis to consumption or raw materials, and households are subject to a cash-in-advance constraint, similar to equation (1) above, where now $M$ stands for fiat money. The representative firm is 
also subject to a liquidity-in-advance constraint for their raw material purchases. Moreover and realistically, I assume that the firm can hold both fiat money and highly liquid securities, say, ABS. The return on ABS, including liquidity services, is also a function of its liquidity coefficient, indicated by $\theta$ in the formal model $(0 \leq \theta \leq 1)$. Clearly, if $\theta=0$, ABS cannot be employed to satisfy the firm's liquidity constraint, and the firm will hold liquidity entirely in the form of fiat money. On the other hand, if $\theta=1, \mathrm{ABS}$ would be perfect substitutes for fiat money and, under normal circumstances, will return-dominate the latter. Thus, I will assume that if $\theta=1$, firms would prefer to hold their entire liquidity portfolio in ABS. The formal model considers intermediate cases but the two limit cases are enough for illustration.

Liquidity Crunch is defined as a sudden exogenous fall in parameter $\theta$. For motivation, this can be thought of as a run on ABS along Diamond-Dybvig (1983) lines. Consider the case in which, initially, $\theta=1$ and as a result of Liquidity Crunch $\theta$ goes all the way down to 0 . Since the return on ABS prior to crisis is higher than the return on fiat money, return on the liquid portfolio that the firm is constrained to hold in advance will be lower after Liquidity Crunch - which increases the cost of raw materials and, if the production function satisfies Inada's conditions, induces a fall in output. If consumers were the only holders of fiat money and money supply was given, the slump would cause a rise in the price level, because output contraction would bring about a fall in the demand for fiat money. But in this model there is an additional effect pointing in the opposite direction because, as noted, Liquidity Crunch provokes a massive switch in firms' liquid portfolio from ABS to fiat money. This switch can offset the fall in the demand for money from households and cause price deflation. The model can, thus, rationalize price deflation even though the cards were stacked against it by the assumption that households are subject to a cash-in-advance constraint.

The model can be extended to a growth context in which the liquidity-in-advance constraint applies to investment. In an AK model in which output is proportional to the stock of capital, one can show that the rate of capital accumulation is a negative function of the opportunity cost of liquidity. Thus, for instance, a Liquidity Crunch would bring about a fall in growth, i.e. sluggish recovery. Moreover, if liquidity-inadvance also applies to the purchase of raw materials, Liquidity Crunch will bring about output contraction on impact, possibly accompanied by price deflation (as in the previous paragraph).

Some policy experiments in terms of this model are conducted in Calvo (2016, Chapter 5). Here I just like to note that, despite its simplicity, the model captures several realistic features associated with Liquidity Crunch. This suggests that policies that aim at restoring the economy's vitality after Liquidity Crunch should pay special attention to factors that caused Liquidity Crunch and moderate its effects. Actually, some popular policies that do not address those issues may fail to work. For instance, an increase in money supply or government expenditure would be totally ineffective, unless they help to restore ABS' liquidity without 
simultaneously provoking a large drop in their pure rates of return (i.e., rates of return that do not include liquidity services). 


\section{References}

Bordo, Michael D., and Athanasios Orphanides (eds.), 2013. The Great Inflation The Rebirth of Modern Central Banking; Chicago, IL: University of Chicago Press.

Buffie, Edward F., and Manoj Atolia, 2012. "Resurrecting the Weak Credibility Hypothesis in Models of Exchange-Rate-Based Stabilization," European Economic Review, Vol. 56(3), pp. 361-372.

Brunnermeier, Markus K., 2009. "Deciphering the Liquidity and Credit Crunch 2007-2008," Journal of Economic Perspectives, AEA, vol. 23(1), pp 77-100, Winter.

Bruno, Michael, Guido Di Tella, Rudiger Dornbusch, and Stanley Fischer, 1988. Inflation Stabilization - The Experience of Israel, Argentina, Brazil, Bolivia and Mexico; Cambridge, MA: MIT Press.

Bruno, Michael, Stanley Fischer, Elhanan Helpman, and Nissan Liviatan, with Leora (Rubin) Meridor, 1991. Lessons of Economic Stabilization and Its Aftermath; Cambridge, MA: MIT Press.

Caballero, Ricardo J., Emmanuel Farhi, and Pierre-Olivier Gourinchas, 2016. "Safe Asset Scarcity and Aggregated Demand," American Economic Review, vol 106(5), pp. 513-518.

Cagan, Phillip, 1956. "The Monetary Dynamics of Hyperinflation," in M. Friedman (ed.) Studies in the Quantity Theory of Money, Chapter II.

Calvo, Guillermo, 1978. "On the Time Consistency of Optimal Policy in a Monetary Economy," Econometrica 46, November, pp. 1411-1428.

Calvo, Guillermo, 1983. "Staggered Prices in a Utility Maximizing Framework," Journal of Monetary Economics, September, pp. 383-398.

Calvo, Guillermo, 1986 a. "Fractured Liberalism: Argentina under Martínez de Hoz," Economic Development and Cultural Change, 34, 3, pp. 511-533.

Calvo, Guillermo, 1986 b. "Temporary Stabilization: Predetermined Exchange Rates," Journal of Political Economy, 94, December, pp. 1319-1329.

Calvo, Guillermo, 1986 c. "Incredible Reforms," in Debt, Stabilization and Development, edited by G. Calvo, R. Findlay, P. Kouri and J. Braga de Macedo; Basil 
Blackwell for World Institute for Development Economics Research, United Nations, Chapter 10. Reprinted in Calvo (1996, Chapter 15).

Calvo, Guillermo, 1988. "Servicing the Public Debt: The Role of Expectations," American Economic Review, 78, September, pp. 647-671. Reprinted in Calvo (1996).

Calvo, Guillermo, 1991. "The Perils of Sterilization," IMF Staff Papers 38, December, pp. 921-26. Reprinted in Calvo (1996, Chapter 13).

Calvo, Guillermo, 1996. Money, Exchange Rates, and Output; Cambridge, MA: MIT Press.

Calvo, Guillermo, 1998. "Capital Flows and Capital-Market Crises: The Simple Economics of Sudden Stops," Journal of Applied Economics (CEMA), 1(1), pp. 35-54. Reprinted in Calvo (2005).

Calvo, Guillermo, 2005. Emerging Capital Markets in Turmoil: Bad Luck or Bad Policy? Cambridge, MA: MIT Press.

Calvo, Guillermo, 2012. "Financial Crises and Liquidity Shocks: A Bank-Run Perspective," European Economic Review, April, pp. 317-326.

Calvo, Guillermo, 2016. Macroeconomics in Times of Liquidity Crises: Searching for Economic Essentials; Cambridge, MA: MIT Press, forthcoming.

Calvo, Guillermo, Fabrizio Coricelli, and Pablo Ottonello, 2012. "The Labor Market Consequences of Financial Crises With or Without Inflation: Jobless and Wageless Recoveries," NBER Working Paper 18480.

Calvo, Guillermo, Fabrizio Coricelli, and Pablo Ottonello, 2013. "Jobless Recoveries During Financial Crises: Is Inflation the Way Out?" NBER Working Paper 19683. Forthcoming in Macroeconomic and Financial Stability: Challenges for Monetary Policy, edited by Sofia Bauducco, Lawrence Christiano and Claudio Raddatz. Santiago, Chile.

Calvo, Guillermo, and Allan Drazen, 1998. "Uncertain Duration of Reform: Dynamic Implications," Macroeconomic Dynamics, 2, December, pp. 443-455. Reprinted in Calvo (2005 Chapter 8).

Calvo, Guillermo, and Pablo Guidotti, 1990. "Indexation and Maturity of Government Bonds: An Exploratory Model," in R. Dornbusch and M. Draghi (eds.) Capital Markets and Debt Management, New York, NY: Cambridge University Press, pp. 52-82. Reprinted in Calvo (1996). 
Calvo, Guillermo, Alejandro Izquierdo and Rudy Loo-Kung, 2013. "Optimal Holdings of International Reserves: Self-insurance against Sudden Stop," Monetaria, Centro de Estudios Monetarios Latinoamericanos, CEMLA, January-June, pp. 1-35.

Calvo, Guillermo, Alejandro Izquierdo and Luis-Fernando Mejia, 2016. "Systemic Sudden Stop: The Relevance of Balance-Sheet Effects and Financial Integration," in Calvo (2016).

Calvo, Guillermo, and Carmen M. Reinhart, 2002. "Fear of Floating," Quarterly Journal of Economics, 117 (2), pp. 379-408.

Calvo, Guillermo, and Carlos A. Végh, 1993. "Exchange-Rate-Based Stabilisation under Imperfect Credibility," in H. Frisch and A. Worgötter (eds.) Proceedings from IEA Conference on Open-Economy Macroeconomics; Hampshire, UK: Macmillan Press Ltd, pp. 3-28. Reprinted in Calvo (1996, Chapter 18).

Calvo, Guillermo, and Carlos A. Végh, 1995. "Fighting Inflation with High Interest Rates: The Small-Open-Economy under Flexible Prices," Journal of Money, Credit, and Banking, 27, pp 49-66.

Cavallo, Eduardo A., and Jeffrey A. Frenkel, 2008. "Does openness to trade make countries more vulnerable to sudden stops, or less? Using gravity to establish causality," Journal of International Money and Finance, Elsevier, vol. 27(8), pp. 14301452, December.

Cipolla, Carlo M., 1987. Money in Sixteen-Century Florence, Berkeley, CA: University of California Press.

Clower, Robert, 1967. "A Reconsideration of the Microfoundations of Monetary Theory" Western Economic Journal, 6 (1), pp. 1-9.

Corsetti, Giancarlo, and Luca Dedola, 2016. "The 'Mystery of the Printing Press' Monetary Policy and Self-Fulfilling Debt Crises," CEPR DP11089, February.

Diamond, Douglas W., and Philip H. Dybvig, 1983. "Bank Runs, Deposit Insurance and Liquidity," Journal of Political Economy, 91(3), pp 401-419.

Dornbusch, Rudiger, and Mario Henrique Simonsen, 1983. Inflation, Debt, and Indexation; Cambridge, MA: The MIT Press.

Eichengreen, Barry, 2015. Hall of Mirrors: The Great Depression, the Great Recession, and the Uses-and Misuses - of History; Oxford, UK: Oxford University Press.

Fontaine, Juan Andres. 1996. "La Construcción de un Mercado de Capitales. El caso de Chile," Banco de Reconstruccion y Desarrollo/Banco Mundial. 
Friedman, Milton, 1971, "Government Revenue from Inflation," Journal of Political Economy, 79, 4, pp. 846-856.

Friedman, Milton, 1977. "Nobel Lecture: Inflation and Unemployment" Journal of Political Economy, Vol. 85, No. 3 (June), pp. 451-472.

Friedman, Milton, 1994. Money Mischief: Episodes in Monetary History, Orlando: FL, Harcourt Brace \& Company.

Friedman, Milton, and Anna J. Schwartz, 1963. A Monetary History of the United States, 1867-1960; Princeton, NJ: Princeton University Press.

Gesell, Silvio, 1916. The Natural Economic Order; reprinted by Isha Books, New Delhi, 2013. The date corresponds to the first edition in German, as reported in Keynes (1936, Chapter 23).

Gopinath, Gita, 2015. "The International Price System," Jackson Hole Proceedings, forthcoming.

Gordon, Robert J., 2011. "The History of the Phillips Curve: Consensus and Bifurcation," Economica 78, pp. 10-50.

Gorton, Gary, and Andrew Metrick, 2012. "Securitized Banking and the Run on Repo," Journal of Financial Economics 104, pp. 425-451.

Gorton, Gary, and Tyler Muir, 2015. "Mobile Collateral versus Immobile Collateral," manuscript, Yale University, July 29.

Guidotti, Pablo E., and Manmohan S. Kumar, 1991. "Domestic Public Debt of Externally Indebted Countries," Ocassional Paper No. 80, International Monetary Fund, Washington D.C.

Hahn, F.H, 1965. "On some Problems of Proving the Existence of an Equilibrium in a Monetary Economy," in F.H. Hahn and F.P.R. Brechling (editors) The Theory of Interest Rates, London, UK: Macmillan \& Co. Ltd., Chapter 6.

Hicks, John R., 1937. "Mr. Keynes and the “Classics”; A Suggested Interpretation,” Econometrica Vol. 5, 2, April, pp. 147-159.

Ilzetzki, Ethan, Enrique G. Mendoza, Enrique, and Carlos A. Végh, 2013. "How Big (Small?) are Fiscal Multipliers?" Journal of Monetary Economics, Elsevier, vol. 60(2), pp. 239-254

Keynes, John M., 1936. The General Theory of Employment, Interest and Money. Reprinted by Macmillan \& Co. Ltd, London, UK, 1961. 
Kiguel, Miguel A. and Nissan Liviatan, 1994. Exchange-Rate Based Stabilizations in Argentina and Chile: A Fresh Look" in Frameworks for Monetary Stability, edited by Tomás J. T. Baliño and Carlo Cottarelli, International Monetary Fund, Washington DC.

Kiyotaki, Nobuhiro, and John Moore, 1997. “Credit Cycles," Journal of Political Economy, Vol. 105, No. 2 (April) pp. 211-248.

Koo, Richard C., 2009. The Holy Grail of Macroeconomics: Lessons from Japan's Great Recession; Hoboken, NJ: John Wiley and Sons (Asia).

Krugman, Paul, 2011. "Mr. Keynes and the Moderns," Voxeu.org, June 21.

Kydland, Finn, and Edward C. Prescott, 1977. "Rules Rather than Discretion: The Inconsistency of Optimal Plans," Journal of Political Economy, 85, pp. 473-493.

Lara Resende, André, 2016. "A Teoria da Política Monetária: reflexōes sobre um caminho sinuoso e inconclusivo;" in E. Bacha, ed., A Crise Fiscal e Monetária Brasileira: ensaios em homenagem a Fábio O. Barbosa; editora Civilização Brasileira forthcoming september. English version online http://iepecdg.com.br/wpcontent/uploads/2016/03/The-Theory-of-Monetary-Policy5.pdf

Lewis, Karen K., 2016. "Peso Problem," The New Palgrave Dictionary of Economics. Second Edition. Edited by Steven N. Durlauf and Lawrence E. Blume. Palgrave Macmillan, 2008. The New Palgrave Dictionary of Economics Online. Palgrave Macmillan, May.

Little, I.M.D., Richard N. Cooper, W. Max Corden and Sarath Rajapatirana, 1993. Boom, Crisis, and Adjustment - The Macroeconomic Experience of Developing Countries. The International Bank for Reconstruction and Development/The World Bank; Oxford University Press.

Lucas, Robert, 1972. "Expectations and the Neutrality of Money". Journal of Economic Theory 4 (2), pp. 103-124.

Lucas, Robert, 1976. "Econometric Policy Evaluation: A Critique". CarnegieRochester Conference Series on Public Policy 1, pp. 19-46.

McKinnon, Ronald I., 2013. The Unloved Dollar Standard: From Bretton Woods to the Rise of China, Oxford, UK: Oxford University Press.

Merler, Silvia, and Jean Pisani-Ferry, 2012. "Sudden Stops in the Euro Area," Bruegel Policy Contribution, March 29.

Minsky, Hyman P., 2008 a. Stabilizing an Unstable Economy, ebook, McGraw Hill. 
NYT, 2008. "Greenspan Concedes Error on Regulation," New York Times, October 23. Column by Edmund L. Andrews.

Obstfeld, Maurice, and Kenneth Rogoff, 1983. "Speculative Hyperinflations in Maximizing Models: Can We Rule Them Out?" Journal of Political Economy, 91, No. 4, August, pp. 675-687.

Obstfeld, Maurice, and Kenneth Rogoff, 1986. "Ruling Out Divergent Speculative Bubbles," Journal of Monetary Economics, 17, May, pp. 346-362.

Ohanian, Lee E., 2016, "The Great Recession in the Shadow of the Great Depression: A Review Essay on 'Hall of Mirrors: The Great Depression, The Great Recession and the Uses and Misuses of History'," NBER Working Paper 22239.

Papageorgiou, Demetris, Michael Michaely and Armeane M. Choksi, 1991. Liberalizing Foreign Trade. The International Bank for Reconstruction and Development/The World Bank. Basil Blackwell, Inc.

Patinkin, Don, 1965. Money, Interest, and Prices; New York, NY: Harper and Row Publishers.

Phelps, Edmund S., 1972. Inflation Policy and Unemployment Theory. W. W. Norton, New York.

Queraltó, Albert. (2013). "A model of slow recoveries from financial crises." FRB International Finance Discussion Paper 1097.

Reinhart, Carmen M., and Vincent R. Reinhart, 2010. "After the Fall," NBER Working Paper 16334, September.

Rodríguez, Carlos Alfredo, 1982. "The Argentine Stabilization Plan of December 20"th" World Development, Vol. 10, 9, pp. 801-811.

Sargent, Thomas J., 1982. "The Ends of Four Big Inflations," in R.E. Hall (ed.) Inflation: Causes and Effects; Chicago, IL: University of Chicago Press.

Sargent, Thomas J., 1991. Conquest of American Inflation; Princeton, NJ: Princeton University Press.

Sargent, Thomas J., 1983. "Stopping Moderate Inflations: The Methods of Poincaré and Thatcher," in Dornbusch and Simonsen (1983, Chapter 4).

Sargent, Thomas J., and Neil Wallace, 1973. "The Stability of Models of Money and Perfect Foresight," Econometrica, 41, pp. 1043-1048. 
Sargent, Thomas J., and Neil Wallace, 1981, "Some Unpleasant Monetarist Arithmetic," Quarterly Review, Federal Reserve Bank of Minneapolis, 5, 3, pp. 1-17.

Shiller, Robert J., 1998. "Indexed Units of Account: Theory and Assessment of Historical Experience," NBER Working Paper No 6356, January.

Taylor, Alan M., 2015. "Credit, Financial Stability, and the Macroeconomy," Annual Review of Economics, vol 7(1), pp. 309-339.

World Economic Outlook (WEO), 2010. Recovery, Risk and Rebalancing, Chapter 2, International Monetary Fund, Washington D.C., October.

World Economic Outlook (WEO), 2016. Too Slow for Too Long, Chapter 2, International Monetary Fund, Washington D.C., April.

Woodford, Michael, 2003. Interest and Prices: Foundations of a Theory of Monetary Policy, Princeton, NJ: Princeton University Press. 